\title{
A Short Note about "Humanitarian War"
}

\author{
Liam O'Hagan
}

\begin{abstract}
The justification of NATO actions in Kosovo in "humanitarian" terms leads us to examine what exactly is meant by this concept, whose definition is not exactly clear. Indeed, the term suggests something different when used by "humanitarian organizations" such as the ICRC, than when used by state actors. This is not to say that the actions of NATO in Kosovo, which may be better understood in conventional human rights terms, are necessarily invalid. Rather, it is to drawattention to the differing interpretations of the concept, the consequences of which are significant for all involved.
\end{abstract}

\section{Résumé}

La justification des actions de l'OTAN au Kosovo en termes "humanitaires" nous force à examiner qu'est-ce quel'on entend exactement parce concept, dont la définition n'est pas tout à fait claire. De fait, le termesuggèrequelque chosedefort différent lorsqu'utilisé par des «organisations humanitaires» commele CICR, et lorsqu'utilisé par des intervenant étatiques. Il ne s'agit pas d'affirmer que les actions de l'OTAN au Kosovo, qui devraient de fait plutôt se concevoir en termes de droits humains conventionnels, sont nécessairement sans validité. Il s'agit plutôtd'attirerl'attention surune différenced'interprétationd'un concept, dont les conséquences sont significatives pour toutes les parties impliquées.

In the wake of the Rwandan genocide of 1994, much was written about the dangers of humanitarianism being misused as an excuse for political inaction. It was suggested that there was a danger that humanitarian action can become

Liam O'Hagan is a Ph.D. candidate and Researcher, Department of Politics, The Queen's University of Belfast, Belfast, Northern Ireland, United Kingdom. merely "a welcome focal point," and a way of showing that "something is being done," in situations where the international community will not commit the necessary resources toward finding a political solution. ${ }^{1}$ It was further argued that the construction of such an event as a "humanitarian disaster" effectively helps to depoliticize it, rendering it a simplecase of saving the lives of victims, almost devoid of the broader context.

Five years later, it appears that humanitarianism is again in danger of being misused, but this time as a justification for doing too much. Tony Benn, the British Member of Parliament and a critic of the NATO operations in Kosovo, noted that, "they say that it is a war for humanitarian purposes. Can anyone name any war in history fought for humanitarian purposes? Would the Red Cross have done better with stealth bombers and cruise missiles?" 2

In certain respects, his observation is misleading, but only so if one recognizes the confusion that surrounds the discourse of humanitarianism. In fact, Benn is distinguishing the kind of action carried out by the "humanitarian organizations," such as the Red Cross and a variety of humanitariannon-governmental organizations (NGOs), which is far removed from the activities of NATO - and indeed from other cases where state actors have intervened militarily under a "humanitarian banner."

The concept of humanitarianism is in some ways contested, or at least means different things to different people. Larry Minear and Thomas Weiss have argued that "the core meaning of humanitarianism revolves around a commitment toimprove thehumancondition. ${ }^{\prime 3}$ At face value, this would appear to be a fairly broad offer and it is likely that most other "political" orideological doctrines would claim to offer something similar. In further work by the authors and their wider project of research, the humanitarian imperative is defined as an individual belief that wherever there is human suffering the international humanitarian system must respond, regardless of political considerations. ${ }^{4}$

For the Red Cross, the principle of humanity is the root of humanitarianism. This principle is defined by Jean Pictet as the sentiment or attitude of someone who shows himself/herself to behuman, by which he means someone who is good to his or her fellow beings. Therefore, humanity becomes a sentiment of active goodwill towards humankind. ${ }^{5}$ The liberal humanist roots of the position have come under examination by some authors, and humanitarianism has traditionally encompassed a whole spectrum of activity; indeed, it has meant different things to different people atdifferent times, and continues to do so. ${ }^{6}$ Nonetheless, it appears that whatever the philosophical underpinnings of humanitarianism, the term is used most readily, and perhaps most appropriately, in terms of the action of humanitarian organizations such as the International Committee of the Red Cross (ICRC) and a variety of NGOs.

For the humanitarian organizations such as the Red Cross, there is an obvious lack of military enforcement in their action, which suggests that the idea of "humanitarian war" is something of an oxymoron. The Red Cross has an obvious role in terms of international humanitarian law, and relief agencies more generally are seen mostly to specialize in one or more of the five activities of: food distribution, provision of shelter, water, sanitation and medical care. ${ }^{7}$ The way in which they carry out their work is also governed by a series of principles which help to define these organizations. For the Red Cross, the principles of impartiality, neutrality and independence are perhaps most important. While impartiality supports the aim of providing for all "victims" in 
a conflict, neutrality seeks to ensure that organizations do not take any side in conflict. This is clearly not the kind of action which NATO is carrying out in Kosovo. The independence principle aims to ensure heedom from the pressure exerted by any other authority, and would ensure a "distance" from organizations such as NATO.8 Such principles are deemed to be crucially important for "humanitarian organizations" in positioning themselves and gaining access for their work. Not all organizations will operate on the basis of these principles and others will interpret them differently. In particular, the neutrality principle is controversial in cases where groups feel that they have to engage more critically with the dynamics of a situation. Kosovo is perhaps a case in point. Nonetheless, however problematic and contested the principles may be, they do to some extent represent a demarcation of territory.

This granted, it is not necessarily the case, however, thatwhatsuchhumanitarian organizations desire as outcomes to a particular situation will necessarily be at odds with the actions of an organization such as NATO. On March 25th, George Robertson the British defence secretary claimed that NATO's aim was "clear cut," and was to "avert an impending humanitarian catastrophe by disrupting the violent attacks being carried out by the Yugoslav security forces against the Kosovan Albanians.,99 The idea of a humanitarian catastrophe is one that would not be out of place in much humanitarian NGO literature. Indeed, some humanitarian NGOs may be supportive of enforcement action from NATO, given that they are often calling for so-called "political solutions" to situations where the limitations of their humanitarian action are clear. Kosovo may represent such a case, although it is likely that the sole use of air strikes would not be the chosen means. 10

A problem also arises where a military organization such as NATO is heralded as a "humanitarian alliance."n The military enforcement capabilities of NATO may be used, in certain cases such as that of Kosovo, in an attempt to

Refuge, Vol. 18, No.3 (August 1999) put an end to human rights abuses. In order to do this, if air strikes are chosen as the means, it is probably"inevitable that civilian casualties will result. For some, state intervention in such cases is clear-cut and not the subject for conceptual debate. $1^{2}$ Others have correctly highlighted the problems with state-led intervention for "humanitarian purposes," such as the abuse of the concept and its selective use. ${ }^{13}$ What is necessary is that the differences between this type of action and that of the humanitarian organizations be clearly recognized and demarcated. I I

\section{Notes}

1 See, e.g., A. Destexhe, foreword to Populations in Danger 1995: A Medecins Sans Frontieres Report (London: M€decins Sans Frontieres, 1995). See also, African Rights, "Humanitarianism Unbound? Current dilemmas facing multi-mandate relief operations in political emergencies," Discussion Paper No.5, November 1994. This report claims that in the light of governments incorporating "humanitarian" projects into their foreign policy, projects are likely to be chosen that best serve countries' "political" objectives. In addition to this, governments use the fact that they help to finance humanitarian organizations projects to try to influence the priorities of these organizations toward the adoption of policies whose results are likely to suit the state's own particular objectives. See also the report of the Joint Evaluation of Emergency Assistance to Rwanda: "The International Response to Conflict and Genocide: Lessons from the Rwanda Experience," and the Eurostep report, "Lessons from Rwanda: The Argument for a more coherent European Policy on the Great Lakes Region", cited at «http:www.oneworld.org/eurostep/ greatlak.htm»

2. Cited in TheIndependent, The Monday Review, March 29, 1999, 4.

3. L. Minear, and T. Weiss, HumanitarianAction in Times of War (Boulder, CO: Lynne Rienner, 1993), 7. It is worth noting how the term 'humanitarian' has seldom been delineated with any precision in international law, including, in particular, the Geneva Conventions.

4. T. Weiss, and C. Collins, Humanitarian Challenges and Intervention: World Politics and the Dilemmas of Help (Boulder, CO: Westview Press, 1996), 219.

5. J. Pictet, commentary on The Fundamental Principles of the Red Cross (Geneva: Henry Dunant Institute, 1979) 20-21.

6. See, D. Campbell, "Why Fight: Humanitarianism, Principles and Post-structuralism",inMillennium 27, no. 3, 497-521; and also, D. Macey, The Lives of Michel Foucault (London: Vintage 1993), 410--45.

7. A. Natsios, "NGOs and the UN system in complex humanitarian emergencies: conflictorcooperation?," in Third World Quarterly 16, no. 3 (1995): 407.

8. See, J. Pictet, commentary on The Fundamental Principles of the Red Cross (Geneva:

Henry Dunant Institute, 1979). An interesting analysis is that ofF. Kalshoven, "Impartiality and Neutrality in Humanitarian Law and Practice." Extract from International Review of the Red Cross (NovemberDecember 1989) 520. See also, J. Pictet, op. cit., 37-51. See also The Fundamental Principles of the Red Cross and Red Crescent (Geneva: ICRC Publications, 1996), 12-15. See also Statutes of the International Committee of the Red Cross, extract from the International Review of the Red Cross, no. 263, March-April 1988.

9. Cited in the Guardian, Tuesday, May 4, 1999,15.

10. The question of relationships with the military and state actors more generally is the subject of much debate within humanitarian NGOs at present.

11. See, the Guardian, Tuesday, May 4,1999, op. cit., and the Sunday Times, April 4, 1999,23.

12. See, B. Kouchner, "Morals of Urgent Need," in Armed Conflict and Other Disasters, edited by F. Kalshoven (London: Martinus Nijhoff Publishers, 1989),5559.

13. See, O. Ramsbotham, and T. Woodhouse, Humanitarian Intervention in Contemporary Conflict; a Reconceptualisation (Oxford: Polity Press, 1996), or N. J. Wheeler, "Humanitarian Intervention and World Politics," in J. Baylis and S. Smith, The Globalisation of World Politics (Oxford: Oxford University Press, 1997). o

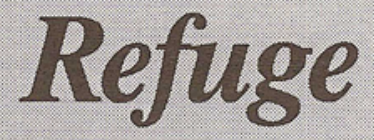

Canada's Periodical on Refugees Available from:

Centre for Refugee Studies

Fax: (416) 736-5837

Email: refuge@yorku.ca http://www.yorku.ca/research/crs 